DOI 10.36622/VSTU.2021.52.4.005

UDC 691.33

I. Popov ${ }^{1}$, A. Levchenko ${ }^{2}$

\title{
EXPERIMENTAL INVESTIGATION OF INTERNAL FRICTION IN RUBBER CONCRETE AND FIBER-REINFORCED RUBBER CONCRETE*
}

\author{
Voronezh State Technical University ${ }^{1,2}$ \\ Voronezh, Russia
}

\begin{abstract}
${ }^{1}$ PhD in Engineering, Researcher of the Research Center on Dynamics of Solids and Structures, e-mail:89042149140@mail.ru

${ }^{2}$ PhD Candidate, Lecturer of the Dept. of Building Structures, Soils and Foundations named after Professor Yu. M. Borisov, e-mail: alevchenko@vgasu.vrn.ru
\end{abstract}

\begin{abstract}
Statement of the problem. The paper is devoted to the experimental identification of damping for such materials as butadiene rubber (BR) and cis-butadiene low-molecular weight rubber (SKDN-N) based concrete and fiber-reinforced rubber concrete by means of the Impulse Excitation Technique (IET).

Results. It was found that BR based concrete with or without fiber-reinforcement shows more obvious viscoelastic properties than the corresponding materials based on SKDN-N rubber. The addition of steel fiber reduces internal friction in the material, while propylene fiber has the opposite effect. This is due to the fact that the fibrous propylene acts as an additional damping material, which enhances energy dissipation under dynamic loading.

Conclusion. The internal friction in the rubber concrete and fiber-reinforced rubber concrete was measured for the first time. The obtained data are the additional microstructural characteristics of polymer concrete, which describes its viscosity. The real values of the investigated quantities have been determined, which makes it possible to use the models with fractional derivatives in the calculations of building structures made of rubber concrete and fiber-reinforced rubber concrete for dynamic loads, taking into account the phenomenon of viscoelasticity.
\end{abstract}

Keywords: internal friction, rubber concrete, fiber-reinforced rubber concrete, impulse excitation technique.

Introduction. In traditional engineering practice, while performing structural calculations, the assumption that the material is purely elastic is commonly made. In the case of static loads, it is fully justified, since the calculation results are in good agreement with the actual values.

However, when dynamic loads are applied, significant differences often arise between the numerical results and the stresses experimentally determined in the elements of actual building structures. This is due to inadequate consideration of the material properties of constructions used in calculations with further adoption of an incorrect engineering decision, which results in material damage and even loss of life. Strictly speaking, perfectly elastic materials

\footnotetext{
(C) Popov I., Levchenko A., 2021

* This research has been supported by the Russian Foundation for Basic Research, Project No. 20-38-70143Stability. The experimental studies have been carried out using the facilities of the Collective Research Center named after Professor Yu. M. Borisov, Voronezh State Technical University, which is partly supported by the Ministry of Science and Education of the Russian Federation, Contract No 075-15-2021-662.
} 
do not exist. All materials are to some extent viscoelastic, i.e., they have both elastic and viscous properties. Taking the phenomenon of viscoelasticity into account allows one to obtain more reliable results of structural calculations considering dynamic effects.

Internal friction, or damping, is an important characteristic describing the viscoelastic behaviour of materials. One of the first fundamental studies in the field of studying the internal friction in metals were conducted by Postnikov [14] and Meshkov [10]. In the monograph [14], the essence of the damping phenomenon in metals has been investigated in sufficient detail, and a classification of the internal friction types based on the nature of its origin has been provided, as well as the results of experimental measurements of internal friction in metals. Postnikov [14] summarized the models of the existing torsion pendulums, gave their detailed description and presented the corresponding drawings. Meshkov [10], in addition to the classification of the types of internal friction in metals, also considered the foundations of the theory of relaxation processes in metals which were studied by Academician Rabotnov [1719]. Later, Lakes [21] presented a review of modern experimental methods for measuring the viscoelastic characteristics of materials, including resonance, and described modernized torsional pendulums. Blatner et al. [20] described in detail the theoretical foundations and gave a clear definition of internal friction, and also demonstrated the results of experiments on measuring internal friction for various metals.

The authors of the present paper have studied internal friction in concrete under the assumption that concrete is a viscoelastic material with time-depending viscosity [22-25]. It has been found that internal friction in concrete decreases during the process of hardening and strengthening. The most significant changes occur at ages up to 14 days, further this trend becomes less and less obvious. This is due to microstructural changes in the concrete material during its hardening and strengthening when the viscous properties gradually disappear, while the elastic properties begin to dominate.

Despite lots of studies in the field of determining internal friction, this issue remains poorly studied for many viscoelastic building materials under dynamic loading. Indeed, once new materials are introduced into production, it becomes necessary to study them in detail in order to fully understand all the processes occurring in the structure of the material under various external impacts. As for rubber concrete, i.e., cis-butadiene low-molecular weight rubber $(\mathrm{SKDN}-\mathrm{N})$ and butadiene-rubber (BR) based concrete and fiber-reinforced rubber concrete, then, to the best of the authors' knowledge, the process of internal friction as a dissipation of mechanical energy has not been previously studied. The developers of these materials and 
their followers have carried out a number of extensive studies of the materials themselves, as well as reinforced structures made of such materials $[1-9,11,12,15,16]$. High compressive $[3,11,7]$ and bending $[5,9]$ strength, crack resistance, resistance to aggressive media [11], as well as a number of other mechanical and operational characteristics were revealed. An immense contribution to the development and investigation of these materials has been made by Borisov [2]. However, the research of these materials has not been completed, since dynamic tests of SKDN-N and BR based concrete and fiber-reinforced rubber concrete have not yet been carried out. Moreover, the study of internal friction and its influence on the mechanical characteristics of materials under dynamic loads are of particular scientific interest, because the above-mentioned polymer concretes has already received a practical application in construction as a material for load-bearing structures operating in aggressive environments.

Therefore in order to completely understand the behavior of these materials under dynamic loads, a full account of their viscoelastic properties is needed by means of new studies of internal friction.

1. Internal friction definition. Several definitions and measures of internal friction are given in the literature. In most works $[10,14,20]$, it is defined as the dissipation of energy in a material under dynamic loading.

There are different measures of internal friction. When applying cyclic loading to a material, the specific damping capacity

$$
\Psi=\Delta W / W,
$$

or the loss factor $\Delta W / 2 \pi W$, and the quality factor

$$
Q=2 \pi W / \Delta W
$$

are introduced to describe the damping phenomena. Here, $W$ is the maximum elastic energy stored during one cycle, and $\Delta W$ is the corresponding energy absorption during that cycle $[14,20]$.

A common measure of damping in the literature is reciprocal of the quality factor, $Q^{-1}$ :

$$
Q^{-1}=\frac{\Delta W}{2 \pi W}=\Psi / 2 \pi
$$

The sinusoidally varying stress and strain, respectively, could be expressed as follows:

$$
\begin{gathered}
\sigma^{*}=\sigma_{0} e^{i \omega t}, \\
\varepsilon^{*}=\varepsilon_{0} e^{i(\omega t-\phi)}=\left(\varepsilon^{\prime}-i \varepsilon^{\prime \prime}\right) e^{i \omega t},
\end{gathered}
$$

and the complex modulus $E^{*}(\omega)$ could be written as 


$$
E^{*}(\omega)=\frac{\sigma^{*}}{\varepsilon^{*}}=E(\omega) e^{i \phi(\omega)}=E^{\prime}(\omega)+E^{\prime \prime}(\omega)
$$

where $\phi$ is the phase lag between stress and strain, $\omega$ is the frequency of vibrations, $E^{\prime}$ is the storage modulus, and $E^{\prime \prime}$ is the loss modulus. In such a situation, the internal friction $Q^{-1}$ could be defined as $[10,14]$

$$
Q^{-1}=\frac{\Delta W}{2 \pi W}=\tan \phi=\frac{E^{\prime \prime}}{E^{\prime}} .
$$

Considering a free vibrating material, the specific damping capacity could be calculated as

$$
\begin{gathered}
\Psi=2 \ln \left(\frac{A_{n}}{A_{n+1}}\right), \\
Q^{-1}=\frac{1}{\pi} \ln \left(\frac{A_{n}}{A_{n+1}}\right),
\end{gathered}
$$

where $A_{n}$ and $A_{n+1}$ are the corresponding amplitudes of $n^{\text {th }}$ and $(n+1)^{t h}$ vibration modes.

Considering equations (3) - (9), it is possible to compare the values of internal friction obtained by different methods using different measures [14].

2. Impulse Excitation Technique (IET). Impulse Excitation Technique (IET) is an advanced method to measure such material characteristics as dynamic Young's and shear moduli, dynamic Poisson's ratio, and internal friction, to investigate the deformation behavior, softening phenomena and relaxation mechanisms and phase transformations in different materials. The experimental studies can be performed at both room and high temperatures. The method is based on the following. A specimen of a well-defined shape and geometry is being put on a wire support as free as possible. The contact between the wire and the sample surface should be established at certain points, so-called nodes. The support location plays a key role in the damping test. If the supporting points do not coincide with the nodes, the damping will be substantially increased. In such a situation, the damping is determined not by the material, but by the test set-up [26]. For each shape of the sample with particular dimensions, the positions of nodes could be calculated. After a small impact is applied to a sample, it starts vibrating. The signal is detected by a microphone and transmitted to the PC. Resonant Frequency and Damping Analyzer (RFDA) software performs fast Fourier transform (FFT), calculates the resonant frequencies, dynamic elastic and shear moduli, dynamic Poisson's ratio, and internal friction. Damping is characterized by the following ratio:

$$
Q^{-1}=k / \pi \omega_{r},
$$

where $k$ is the loss factor, and $\omega_{r}$ is the resonant frequency. 
More details on IET and its applications for measurements of damping could be found in the review [25].

3. Experimental program. The experimental program of this research consists of two major parts. The first part is devoted to the analysis of such basic materials' properties as compressive strength, dynamic Young's modulus, and dynamic Poisson's ratio. Another part of the program is aimed at the measurement of internal friction. For the damping test, three blocks $160 \times 80 \times 40 \mathrm{~mm}$ have been cast for each set of rubber concrete. Damping measurements have been carried out at the age of 7 days at room temperature.

3.1. Materials and components. To investigate the damping in rubber concretes available in the local industry, two types of rubber were used for making specimens, namely: SKDN-N produced by OJSC Efremov Synthetic Rubber Enterprise (Efremov, Russia) and BR produced by Voronezh Factory of Synthetic Caoutchouc (Voronezh, Russia). In order to evaluate the effect of fiber presence in the mixture and the fiber type on materials' internal friction, two types of fibers were used: metal fiber made of steel wire taken from tires and propylene fiber. The main components for rubber concretes are the following:

- low molecular weight cis-polybutadiene rubber SKDN-N (in accordance with TU 38.103515-2005), which is obtained by the polymerization of butadiene under the action of a catalytic system based on nickel salts and organic aluminum compounds;

- technical sulfur (in accordance with GOST 127.1-93) in the form of bright yellow powder with a density of $2070 \mathrm{~kg} / \mathrm{m}^{3}$, and with a melting point of $114{ }^{\circ} \mathrm{C}$;

- vulcanization activator (zinc oxide ZnO in accordance with GOST 10262-73) in the form of white powder with a density of $5600 \ldots 5700 \mathrm{~kg} / \mathrm{m}^{3}$;

- calcium oxide in the form of white powder with a density of $2500 \ldots 2900 \mathrm{~kg} / \mathrm{m}^{3}$ was used as a calcium-containing component;

- fly ash from the Voronezh Powerplant with specific area $2500-2700 \mathrm{~cm}^{2} / \mathrm{g}$ (in accordance with GOST 25818-91);

- ordinary Portland Cement M500 produced in Voronezh by CJSC "EUROCEMENT GROUP";

- steel fiber made of steel wire taken from tires (in accordance with GOST 14311-85);

- propylene fiber (fiber diameter $17-25 \mu \mathrm{m}$, fiber length $3 \mathrm{~mm}$ ) in accordance with EN 14889-2:2006;

- quartz stone and gravel (see Table 1). 
Physical properties of aggregate

\begin{tabular}{|c|c|c|c|}
\hline Aggregate & Fraction dimensions, $\mathrm{mm}$ & Specific gravity & Specific area, $\mathrm{cm}^{2} / \mathrm{g}$ \\
\hline Gravel & $5.000 \ldots 10.000$ & 2.67 & 5.4 \\
\hline Quartz sand & $1.250 \ldots 2.500$ & 2.65 & 33.0 \\
\hline
\end{tabular}

3.2. Proportions of the specimen mix. The proportions of the specimen mix of rubber concrete could vary. For this experiment with locally available materials, only optimized proportions [2] that are being used in the industry are taken for making specimens. Six sets of rubber concrete have been cast. There are SKDN-N rubber-based concrete itself, and the same material reinforced with steel fiber and with propylene fiber. Analogous compositions are applied to BR based concretes. Sample specifications, marks and their proportions of the specimen mix are shown in Table 2.

Sample specifications, marks and proportions of the specimen mix

\begin{tabular}{|c|c|c|c|c|c|c|}
\hline Component/Sample mark & 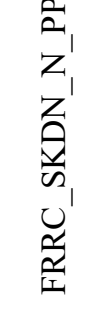 & 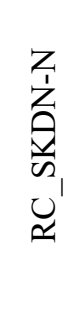 & 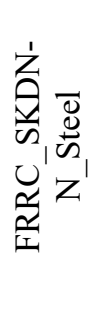 & 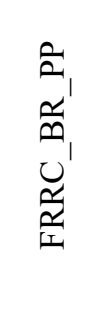 & $\begin{array}{l}\underline{a} \\
\underbrace{\prime} \\
\bigcup^{\prime}\end{array}$ & 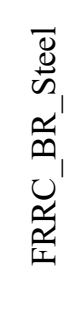 \\
\hline Low molecular weight rubber $\mathrm{BR}, \%$ by mass & - & - & - & 8.2 & 8.0 & 8.2 \\
\hline Low molecular weight rubber SKDN-N, \% by mass & 8.2 & 8,0 & 8.2 & - & - & - \\
\hline Sulfur technical, $\%$ by mass & 4 & 4.0 & 4.0 & 4 & 4.0 & 4.0 \\
\hline Tiuram-D, $\%$ by mass & 0.4 & 0.4 & 0.4 & 0.4 & 0.4 & 0.4 \\
\hline Zinc Oxide, $\%$ by mass & 1.2 & 1.6 & 1.2 & 1.5 & 1.6 & 1.2 \\
\hline Calcium Oxide, $\%$ by mass & 0.4 & 0.5 & 0.4 & 0.5 & 0.5 & 0.4 \\
\hline Fly ash, $\%$ by mass & 7.8 & 7 & 7.8 & 8 & 7 & 7.8 \\
\hline Quartz sand, $\%$ by mass & 24.2 & 24 & 24.2 & 23 & 24 & 24.2 \\
\hline Gravel, $\%$ by mass & 53.45 & 54.5 & 51.3 & 54.05 & 54.5 & 51.3 \\
\hline Steel Fiber, $\%$ by mass & - & - & 2.5 & - & - & 2.5 \\
\hline Propylene fiber, $\%$ by mass & 0.35 & - & - & 0.35 & - & - \\
\hline
\end{tabular}

3.3. RFDA Basic experimental setup. The experimental setup is shown in Fig. 1. RFDA (Resonant Frequency and Damping Analyzer) Basic consists of a PC, wire support, RFDA software, a special microphone to receive the signal, and a mechanical impactor. For testing rubber concrete blocks, a steel wire support system has been designed and manufactured. As it was previously shown by the authors [22], the replacement of standards wire support system by a massive steel wire support does not affect the measurements. The principle is based on the IET. The input parameters are the following: sample shape (dropdown menu), sample di- 
mensions, sample mass, calculation mode, and the value for dynamic Poisson's ratio for the first iteration. The software automatically calculates the positions of the nodal points. As the output, the dynamic Young's and shear moduli, dynamic Poisson's ratio, resonant frequencies, loss factor and internal friction could be obtained (see Fig. 2).

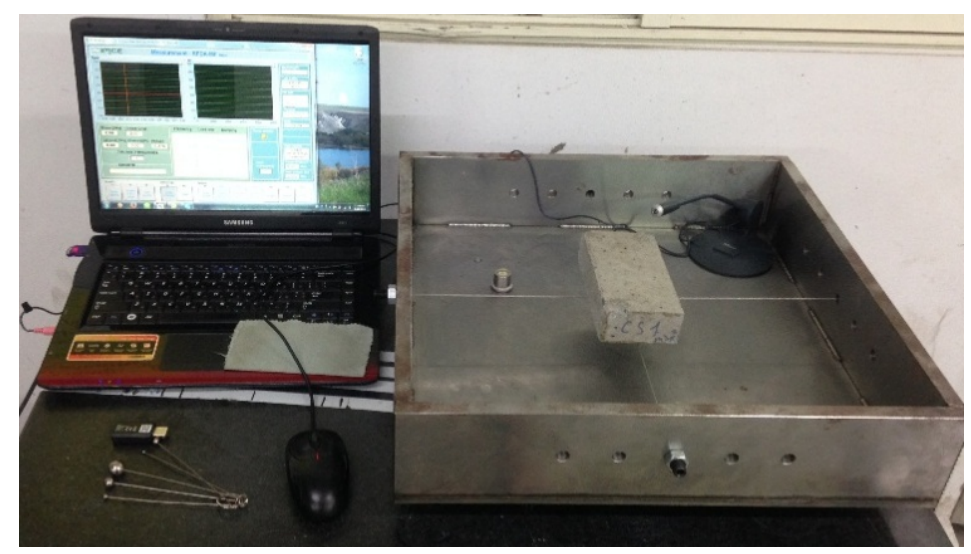

Fig. 1. Experimental setup for the damping test

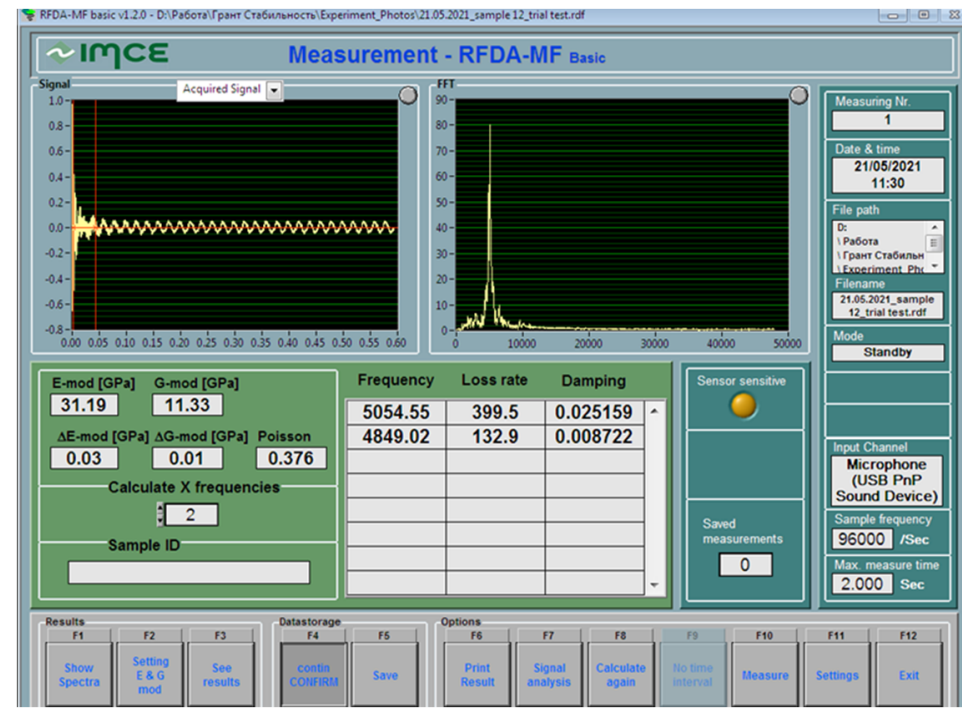

Fig. 2. Resonant Frequency and Damping Analyzer software output

4. Results and discussion. Compressive strength results for rubber concretes are presented in Fig. 3. Unlike Ordinary Portland Cement (OPC) concretes, the design compressive strength of rubber concrete is established during the first day, and it remains almost unchanged for a long time [2]. Comparing RC_SKDN-N with RC_BR, FRRC_SKDN_N_PP with FRRC_BR_PP and FRRC_SKDN_N_Steel with FRRC_BR_Steel in terms of their compressive strength values, it could be noted that BR-based rubber concretes perform from 12 to 13 per cent higher values of the compressive strength rather that SKDN-N rubber-based concretes. For both, SKDN-N and BR addition of $0.35 \%$ by mass of propylene fibre increase compressive 
strength by 4 per cent, whereas the addition of 2.5 per cent by mass of steel fibre increases the compressive strength by 12 to 13 per cent.

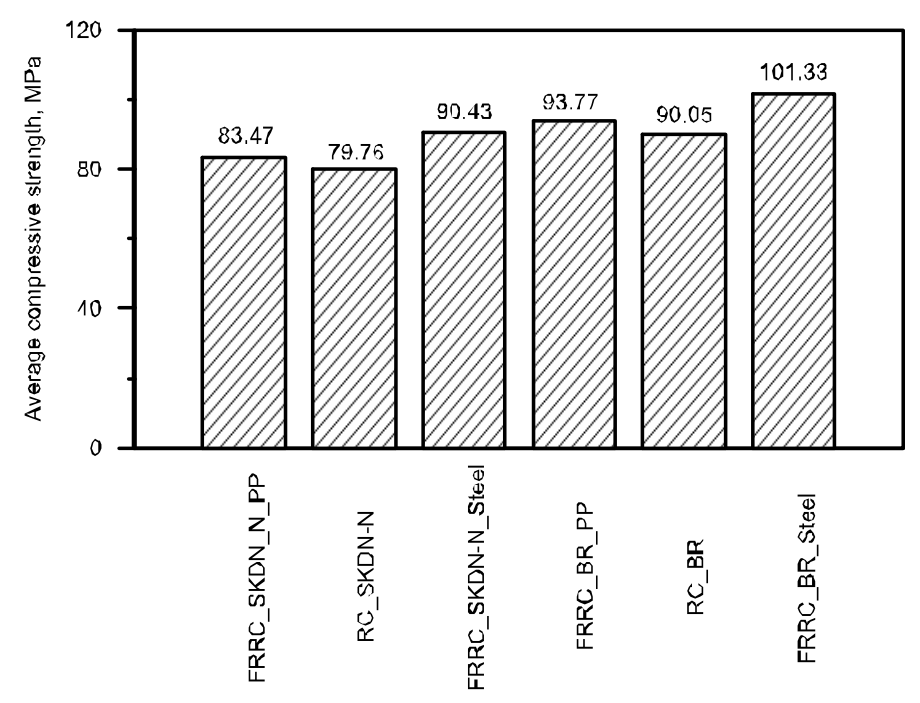

Fig. 3. Compressive strength of the rubber concretes

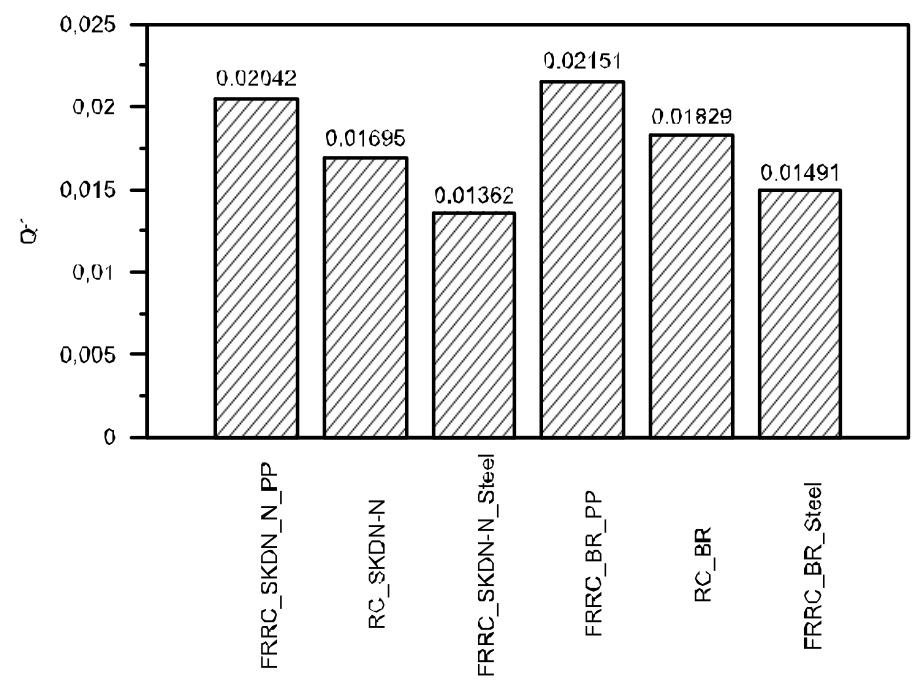

Fig. 4. Internal friction in rubber concretes

Internal friction in different rubber concretes at the age of 7 days is shown in Figure 4. It can be seen that internal friction in RC_BR exceeds the corresponding value for RC_SKDN-N by 7.9 per cent, damping in FRRC_BR_Steel is larger than that for FRRC_SKDN-N_Steel by 9.5 per cent and FRRC_BR_PP differs from FRRC_SKDN-N_PP by 5.3 per cent. Generally speaking, BR based concretes and fiber-reinforced rubber concretes possess higher values $Q^{-1}$ than SKDN-N rubber-based concretes. The introduction of polymer or steel fiber into the mixture does not change this trend. It means that BR based concretes are more viscoelastic than SKDN-N based materials. Indeed, according to the previous studies [2], BR based con- 
crete possesses higher compressive and bending strength rather that SKDN-N rubber concrete, i.e. behaves as a viscoelastic material.

Conclusions. In conclusion, it should be mentioned that based on the results of the reported research, BR based concrete (with or without fiber-reinforcement) shows more obvious viscoelastic properties than the corresponding materials based on SKDN-N rubber. The difference in $Q^{-1}$ for those materials varies from 5.3 to 9.5 per cent. The obtained data are the additional microstructural characteristics of polymer concrete, which is indicative of its viscosity. The actual values of the investigated quantities have been determined, which makes it possible to use the models with fractional derivatives in the calculations of building structures made of rubber concrete and fibre-reinforced rubber concrete for dynamic loads taking into account the phenomenon of viscoelasticity. This research will be extended for investigation of the ageing effect on internal friction of rubber concrete and fiber-reinforced rubber concrete.

\section{References}

1. Barabash D. E. Kompozitsionnye stroitelnye materialy na osnove modifitsirovannykh zhidkikh oligodienov [Composite construction materials based on modified liquid oligodienes]. Nauchnyi vestnik voronezhskogo gosudarstvennogo arkhitekturno-stroitelnogo universiteta. Stroitlesvo i arkhitektura, 2008, no. 4, pp. 81-90.

2. Borisov Yu. M., Panfilov D. V., Kashtanov S. V., Yudin Ye. M. Dispersno armirovannye stroitelnye komposity [Dispersed reinforced building composites]. Stroitelnaya mechanika i konstruktsii, 2010, no. 2(5), pp. 32-37.

3. Borisov Yu. M., Polikutin A. E., Chudinov A. S., Atanov A. Yu. Zadachi i metodika eksperimentalnykh issledovanii normalnykh sechenii izgibaemykh elementov tavrovogo profilya iz armokautona [Problems and the method of experimental investigation of normal sections of T-shaped bending elements made of fiberreinforced rubber concrete]. Nauchnyi vestnik voronezhskogo gosudarstvennogo arkhitekturno-stroitelnogo universiteta. seriya: vysokie technologii. Ekologia, 2011, no. 1, pp. 52-57.

4. Borisov Yu. M., Polikutin A. E., Nguen F. Z. Issledovanie nesushchei sposobnosti normal'nykh sechenii dvusloinykh kautonno-betonnykh izgibaemykh elementov [Investigation of load-bearing capacity of normal sections double-layered rubber-concrete elements]. Vestnik Tsentralnogo regionalnogo otdeleniya RAASN, 2010, no. 9, pp. 133-137.

5. Borisov Yu. M., Potapov Yu. B., Barabash D. E., Polikutin A. E., Panfilov D. V., Pinaev S. A. Konstruktsii spetsialnogo naznacheniya na osnove kaychukovogo betona: monographiya [Special-purpose structures based on rubber concrete: a monograph]. Voronezhskii GASU, Voronezh, 2013.

6. Borisov Yu. M., Polikutin A. E., Nguen F. Z. Napryazhenno-deformirovannoe sostoyanie dvusloinykh kautonno-betonnykh izgibaemykh elementov stroitlnykh konstruktsii [Stress-strain state of double-layered rubber-concrete structural elements]. Nauchnyi vestnik voronezhskogo gosudarstvennogo arkhitekturnostroitelnogo universiteta. Arkhitektura i stroitlesvo, 2010, no. 2, pp. 18-24.

7. Borisov Yu. M. Stroitel'nyye materialy i izdeliya dlya osobykh uslovii ekspluatatsii na osnove zhidkikh kauchukov. Diss. d-ra tekhn. nauk [Construction materials and products for special operating conditions based on liquid rubbers. Dr. eng. sci. diss.], 2005.

8. Meshkov S. I. Vyazkouprugie svoistva metallov [Viscoelastic properties of metals]. Moscow, Metallurgia Publ., 1974.

9. Panfilov D. V., Potapov Yu. B., Kashtanov S. V., Konstantinov I. A. Vliyanie neodnorodnoi struktury fibrokautona na ego prochnost' [Influence of heterogeneous structure of fiber-reinforced rubber concrete on its compressive strength]. Condens Matter Interph, 2014, no. 16 (3), pp. 310-317.

10. Pinaev S. A., Da Foneska F. S. Vliyanie polimertsementnoi zashity na treschinostoikost' zhelezobetonnykh izgibaemykh elementov [Influence of polymer-cement protection on crack resistance of reinforced concrete bending elements]. Nauchnyi vestnik voronezhskogo gosudarstvennogo arkhitekturno-stroitelnogo universiteta. Seriya: Vysokie technologii. Ekologia, 2011, no. 1, pp. 85-88. 
11. Popov I. I., Rossikhin Yu. A., Shitikova M. V. Eksperimentalnye issledovaniya vliyaniya vozrasta betona na velichinu kontaktoi sily i vremeni kontakta pti udare po vyazkouprugoi balke [Experimental investigation of the effect of the concrete age on the contact force and contact time during the impact upon a viscoelastic beam]. Izvestiya Vuzov. Stroitelstvo, 2018, no. 6, pp. 117-126.

12. Postnikov V. S. Vnutrennee trenie v metallakh [Internal friction in metals]. Moscow, Metallurgia Publ., 1974.

13. Potapov Yu. B. [High performance composites based on liquid rubbers]. Aktual'nye problemy stroitel'nogo materialovedeniya (IV Akademicheskie chteniya RAASN): sb. nauch. st. materialov mezhdunar. nauch.tekhn. konf. [Proc. of the International Scientific and Technical Conference (IV Academic Readings of the RAASN) "Actual problems of building materials science"], Penza, 1998.

14. Potapov Yu. B. Kautony - novyi klass korrozionnostoikikh stroitelnykh materialov [Rubber concrete a new class of corrosion resistant construction materials]. Stroitelnye materialy XXI veka, 2000, no. 9, pp. 9-10.

15. Rabotnov Yu. N. Mekhanika deformiruemogo tverdogo tela [Solid mechanics]. Moscow, Nauka Publ., 1988.

16. Rabotnov Yu. N. Polzuchest' elementov konstruktsii [Creep of structural elements]. Moscow, Nauka Publ., 1966.

17. Rabotnov Yu. N. Elementy nasledstvennoi mekhaniki tverdykh tel [Elements of hereditary solid mechanics]. Moscow, Nauka Publ., 1977.

18. Figovskyi O. L., Potapov Yu. B., Panfilov D. V., Kashtanov S. V., Yudin Ye. M. Issledovaniye raspredelenya defectov $\mathrm{v}$ structure fibrokautona metodom Monte-Karlo [Investigation of the distribution of defects in the structure of fibrocouton by the Monte Carlo method]. Vostochno-evropeiskii zhurnal peredovykh tekhnologii, 2014, no. 72, pp. 21-25.

19. Figovskyi O. L., Potapov Yu. B., Polikutin A. E., Nguen Z. F. Prochnost' normalnykh sechenii dvusloinykh izgibaemykh elementov stroitelnykh konstruktsii [Strength of normal sections of two-layer rubber-concrete bending elements of building structures]. Vostochno-evropeiskii zhurnal peredovykh tekhnologii, 2014, no. 72, pp. 14-20.

20. Blanter M. S., Golovin I. S., Neuhäuser H., Sinning H-R. Internal Friction in Metallic Materials. Berlin, Springer, 2007.

21. Lakes R. S. Viscoelastic measurement techniques. Rev Sci Instrum, 2004, no. 75 (4), pp. $797-810$. doi: $10.1063 / 1.1651639$

22. Popov I. I., Chang T. P., Rossikhin Yu. A., Shitikova M. V. Application of impulse excitation technique to investigation of concrete damping and its changes at early ages. IMEAIA 2016: Proceedings of the 2016 International Conference on Informatics, Management Engineering and Industrial Application, Phuket, Thailand, April 24-25, 2016. DEStech Publications Inc, Lancaster, p. 319.

23. Popov I. I., Rossikhin Yu. A., Shitikova M. V. Experimental identification of the fractional parameter for a viscoelastic model of concrete at different ages based on the impulse excitation technique. Advances in Rotor Dynamics, Control, and Structural Health Monitoring. Select Proceedings of ICOVP 2017. Lecture Notes in Mechanical Engineering. Springer Nature Singapore Pte Ltd, 2020 p. 349.

24. Popov I. I., Shitikova M. V. Impulse excitation technique and its application for identification of material damping: an overview. IOP Conf Ser: Mater Sci Eng 2020, no. 962, pp. 1-8. doi: 10.1088/1757-899X/ 962/2/022025

25. RFDA Basic v.1.1 Manual, IMCE N.V. 